\title{
Profession Accountant - vector of development in Russia
}

\author{
Lopukhova N., Erina T. \\ Kazan (Volga region) Federal University \\ Kazan, Russia \\ 4 Butlerova st.
}

\begin{abstract}
Changes in the Russian economy have an impact on different professions and set new goals and objectives for higher education institutions. Therefore, it is necessary to realize what exactly is changing in the work of the accountant: the value of professional judgment of the accountant is growing; new approaches to the creation and presentation of reporting forms integrated reporting are applied; new IT resources appear that take the work of the accountant to a qualitatively new level. All this requires a specialist in accounting new business qualities and competencies. However, the professional standard "Accountant" operating in Russia does not fully reflect these changes. Accountants will need competencies and skills to meet the increasing demands from different stakeholders as barriers between internal and external reporting, financial and nonfinancial performance are removed. At the same time, the accountant should be able not only to use the accounting automation program, but also to generate the necessary indicators and information flows. Further long-term development of the Accounting profession involves a deep subject knowledge, practical experience, as well as a creative approach to solving various problems and problems, developed emotional intelligence, a conceptual vision of the problems and prospects of the company and confident knowledge of IT-technologies.
\end{abstract}

Keywords - profession Accountant, professional standards, Federal accounting standards, IFRS, and the digital economy.

\section{INTRODUCTION}

Russia's economy has undergone major changes in recent years due to both external and internal factors. At the same time, a significant impact on this process is exerted by the desire for maximum integration into the world economy, an increase in the investment attractiveness of business and progress towards the digital economy. In this connection, requirements to specialists in the field of economy and in particular to a profession of the Accountant change.

\section{ANALYSIS OF FACTORS}

\section{INFLUENCING THE PROFESSION OF ACCOUNTANT}

Many factors today have an impact on the formation of a specialist in the field of accounting. Consider a number of factors in more detail and in conjunction with others. In addition, from the point of view of their influence on the professional standard "Accountant". Employer companies in Russia are obliged to apply the developed professional standard when law, for example, establishes accounting requirements if they are public joint stock companies, banks, insurance companies and others. All other companies can apply the standard at will, in particular, in the development of job descriptions, personnel policy and recruitment. However, the company has no right to dismiss an employee who does not meet the requirements of the professional standard. The company can carry out certification and transfer the employee with an insufficient level of qualification to other position. At the same time, leading Russian universities bring educational programs in line with professional standards. In fact, this means that the professional standard can raise the level of profession in the country to a qualitatively new level, or Vice versa.

When drawing up educational programs in higher educational institutions of Russia it is necessary to answer the following questions:

- What influences the future of the Accounting profession?

- What knowledge and skills, as well as personal qualities should a professional successful accountant possess?

- How the young specialist sees his future in the profession, and what to do to meet his expectations?

- How to create a specialist who will be ready for subsequent changes in the profession?

In our opinion, the nearest future of the profession of Accountant in Russia will be formed under the influence of three main factors:

1) The further rapprochement of the Federal accounting standards (FAS) to IFRS.

2) The information needs of the management for managerial decision-making.

3) Requirements of digital economy for knowledge and skills of the expert in the field of accounting.

However, a more global approach to the analysis of factors affecting the Accounting profession is found in the Association of chartered certified accountants (ACCA). In 2016, she identified the following topics for the development of the Accounting profession:

- Regulation and management (Regulation and governance).

- Digital technologies (Digital technologies).

- Customer expectations (Expectations).

- Globalization (Globalization). 


\section{INTEGRATION OF RUSSIA INTO THE INTERNATIONAL ECONOMIC COMMUNITY}

Russia is also involved in the globalization of the economy on a global scale. Russia's integration into the international economic community began with the adoption of the accounting reform Program in Russia in accordance with IFRS. It continued with Russia's accession to the World trade organization (WTO) in 2012. Now another step towards the maximum convergence with IFRS has been made - in 2017, the program for the development of Federal accounting standards (FAS) for 2017-2019 was adopted.

The FAS replaced the Accounting regulations, and in the near future will be edited the old standards, as well as adopted a number of new standards. Thus, not only the status of documents regulating accounting has changed, but also the scope of coverage of objects of accounting supervision and approaches to assessment and reflection in accounting system will increase. This will certainly make accounting and reporting a more reliable source of information for management decisions.

In Russia in recent years, in practice there has been a tendency to increase the importance of tax accounting in comparison with accounting. This is primarily due to the scale of penalties for non-compliance with tax legislation. And in the second place there is simplification of methods of accounting and an assessment of objects of accounting supervision for the purpose of their rapprochement with similar methods in the tax accounting. All this has led to the fact that in practice accounting standards (IAS) are not used effectively. The situation is aggravated by the insufficient set of accounting tools contained in the domestic standards.

To improve the efficiency of the application accounting standards in our country is constantly working to improve them. To this end, in 1998 the program of accounting reform in accordance with IFRS was adopted, and in 2017 the abovementioned program for the development of the FSB was approved. The program is not a normative document, but sets the direction for the development of accounting in Russia. In the near future, we expect a significant leap in the reform of the company under IFRS. It involves the withdrawal from detailed regulation in accounting, and the relevance of the professional judgment of the chief accountant of a specific organization.

For example, there are many gaps and inconsistencies in the Russian accounting standard for property, plant and equipment. In particular, we are talking about changes in the value of fixed assets. It is the revaluation, which results in the initial value of the fixed asset in accordance with its real value. Moreover, it usually falls in the process of its operation. At the same time, depreciation, reducing the initial value of the fixed asset, does not lead to the calculation of its fair value, that is, the market value. Even two similar items of property, plant and equipment may not cost the same for their useful lives, as they are used at varying degrees of intensity. Therefore, deviations in the fair value of fixed assets arise constantly. The depreciation mechanism cannot account for all factors that reduce the value of the non-current asset. Therefore, there is a need for impairment of such asset.

The mechanism of impairment and its essence are disclosed in IFRS, but not mentioned in FAS. However, impairment is stipulated by the draft of the new accounting regulations "fixed assets accounting". Thus, already now there is a possibility of its application. The current law on accounting "the development of Federal standards and recommendations in the field of accounting was transferred to subjects of non-state regulation, one of which is the "national non-state regulator of accounting" methodological center (AMC). If you follow the recommendations of the AMC and note existing GAAP, it minimizes the risks of sanctions for incorrectly reflected in the accounting (financial) statements of the facts of economic life.

Thus, today it is obvious that new tools are needed for the Russian practice of increasing the reliability of accounting data, in particular with respect to non-current assets. Moreover, IFRS remain their most important source. This is, now the role of professional judgment of the accountant significantly increases. It may not be created automatically in the conditions of programs of automation of accounting. In order to make its judgment professional accountant relies not only on the information contained in the database, but also on their experience, taking into account the analysis of various internal and external factors. In this sense, changes in the FSB will give the accountant an even greater opportunity to form their own non-standard judgments that reflect the characteristics of the activities of his company.

In addition, it is possible to identify another promising direction of improving the forms and content of accounting the use of integrated reporting. In many countries of the world, it is attached great importance. Russian companies, investors and other interested parties are also increasingly interested in it. The Range of consumers of such reports is much wider. As part of these reports, the traditional financial indicators are supplemented by a whole block of non-financial indicators that characterize the sustainable development of the company and more fully disclose the model of creating value for the company.

Integrated reporting is becoming more common in the world and in the Russian Federation, which leads to the need for an accountant to form an integrated thinking that will eventually change the role of an accountant from an information provider to a value-creating entity. However, as noted by many experts, today we have only an indicative idea of what is integrated thinking and it cannot be formalized in the form of the necessary skills and work skills.

\section{THE DEVELOPMENT OF THE PROFESSION OF ACCOUNTANT IN TERMS OF THE DIGITAL ECONOMY IN RUSSIA}

In recent years, it has been increasingly believed that the profession of Accountant is losing its relevance. The activities of the accountant are to enter information into the program of automation of accounting. However, the influence of the socalled "Informatization factor" in accounting is mainly 
affected by the procedures for collecting primary information and its primary processing. Actually, there is a substitution of these functions of the ordinary accountant by IT-tools or programs of automation of accounting. Moreover, it is definitely positive for the company: it reduces the complexity of accounting, increases the analyticity of the information, expanding the opportunity of access to information by different users.

In the modern economy of Russia, the role of the accountant as an analyst will increase. In 2017, the President of Russia defined the direction of development of our economy for the next decade: the development of the information society in terms of economic security. In May 2017, the Strategy for the development of the information society in the Russian Federation for 2017-2030 was approved, and in July, the Prime Minister of the Russian Federation approved the program of the digital economy of the Russian Federation. These documents have in fact consolidated Russia's transition to the digital economy.

The term "digital economy" has a very broad interpretation. The Russian government has set serious targets for the development of the so-called industry 4.0, which results in the digital economy. The industrial history of our civilization can be described as follows: industry;

1) Industry 1.0 - the use of water and steam in the

2) Industry 2.0 - the use of electricity in the industry;

3) Industry 3.0 - the use of IT-technologies in the industry;

4) Industry 4.0 - the use of flexible business models and global coverage in the industry thanks to the capabilities of the so-called Internet of things (IOT - Internet of Things) and the integration of "cyber-physical systems" (CPS-CyberPhysical System) into production processes.

Therefore, most technological, economic and managerial decisions, strategies and techniques will not yet fully meet the requirements of the digital economy.

As for the impact of the digital economy on the professional competence of the accountant and one's appointment in the company management system, it can be described as follows:

1) Improving the analytical information collected and processed in the accounting system by automating these processes. Not only all stages of the process of collecting, processing and storing information, but also its receipt from other contractors and transfer to the following contractors should be automated. At the same time, the accountant should be able not only to use the accounting automation program, but also to generate the necessary indicators and information flows.

2) Collecting, processing, storing and providing access to large amounts of economic information become essential in effective management. Global data sets today have been called Big Data (BD). They will form the basis for integrated reporting and provide sufficient information for management decisions.

3) Expansion of the range of consumers of accounting information through the introduction of integrated reporting will lead to the fact that the accountant will need to meet much higher expectations, which were mentioned in the ACCA report. The accountant will need competencies and skills to meet more and more demands from different stakeholders. These requests will increase as barriers between internal and external reporting, financial and non-financial performance are removed. The accountant will have to build a strategic model of behavior both within the company and with external counterparties.

\section{PROFESSIONAL STANDARDS IN ACCOUNTING: PRESENT AND FUTURE}

As rightly noted in the program of the digital economy of the Russian Federation, "The number of training and compliance of educational programs to the needs of the digital economy are insufficient. There is a serious shortage of personnel in the educational process at all levels of education". Training of specialists in the field of accounting must be built so as to teach them correctly and at the same time teach them to develop, because technology and management, and business processes, and the competitive environment, and the tools and job responsibilities of employees, and their attitude to comprehensive security.

\section{USING THE TEMPLATE PROFESSIONAL STANDARDS IN ACCOUNTING: PRESENT AND FUTURE}

All this makes the highest demands on the profession of Accountant, which today in Russia are not reflected in the professional standard "Accountant". It is necessary to agree with the opinion of Barilenko V., Deputy Head of research Department of accounting, analysis and audit of the Financial University under the government of the Russian Federation. He stated that it was unreasonable to limit the level of qualification of accountants to the sixth level. This level corresponds to the competencies that provided by secondary vocational education and higher education at the bachelor's level.

Now awaiting the entry into force of the new version of the professional standard "Accountant", which added two more skill levels to seventh and eighth. These qualification levels can be assigned to the chief accountant, head of accounting Department, head of consolidated financial statements. Moreover, here, one of the main requirements is the availability of higher education - master's degree or specialty. In addition, at the seventh level, it is necessary to know the accounting automation programs, and at the eighth level - to integrate information systems of subsidiaries and dependent companies. A high-level specialist in accounting should not only be able to use IT-resources, but also to manage them. The increase in the level of qualification of an accountant in the professional standard will allow a differentiated approach to the assessment of the accountant's work and will form a large layer of specialists who have mastered the most modern 
knowledge and skills. This will be achieved by requiring a minimum of 120 hours of advanced training in three consecutive calendar years, but not less than 20 hours each year.

In addition, the current professional standard "Accountant" incorrectly presents the limitation of purpose the professional activities of accountants only objectives of financial accounting (level 5), and the formation of the accounting (financial) statements - General labor function (level 6). The functional map of the type of professional activity of the chief accountant describes the corresponding 6th level of qualification five labor functions. In the Federal state educational standard of the higher education in the direction of preparation "Economy" professional competences (PC) in accounting activity are established. There are also only five. We analyze the correspondence of the economist's professional competences to the accountant's labor functions in table 1.

TABLE I. COMPLIANCE OF THE PROFESSIONAL COMPETENCE OF THE ECONOMIST LABOR FUNCTIONS OF THE ACCOUNTANT

\begin{tabular}{|c|c|c|}
\hline $\begin{array}{l}\text { Labour } \\
\text { function }\end{array}$ & $\begin{array}{l}\text { Professional competence } \\
\text { in accounting activities } \\
\text { (PC) }\end{array}$ & $\begin{array}{c}\text { Required competencies } \\
\text { from other kinds of } \\
\text { economic activities }\end{array}$ \\
\hline $\begin{array}{l}\text { 1) } \\
\text { Preparation } \\
\text { of } \\
\text { accounting } \\
\text { (financial) } \\
\text { statements }\end{array}$ & $\begin{array}{l}\text { - ability to document } \\
\text { business transactions, to } \\
\text { carry out accounting of } \\
\text { funds, to develop a work } \\
\text { plan of accounts of } \\
\text { accounting of the } \\
\text { organization and to form } \\
\text { on its basis accounting } \\
\text { transactions (PC-14) } \\
\text { - ability to generate } \\
\text { accounting entries for } \\
\text { accounting sources and the } \\
\text { results of the inventory and } \\
\text { financial liabilities of the } \\
\text { organization (PC-15) } \\
\text { - the ability to draw up } \\
\text { payment documents and } \\
\text { generate accounting entries } \\
\text { for the calculation and } \\
\text { transfer of taxes and fees to } \\
\text { the budgets of different } \\
\text { levels, insurance } \\
\text { premiums-extra-budgetary } \\
\text { funds (PC-16) } \\
\text { - the ability to reflect on } \\
\text { the accounts of accounting } \\
\text { the results of economic } \\
\text { activities for the reporting } \\
\text { period, to make forms of } \\
\text { accounting and statistical } \\
\text { reporting, tax returns (PC- } \\
17 \text { ) }\end{array}$ & $\begin{array}{l}\text { Settlement and } \\
\text { economic activities: } \\
\text { - ability to collect and } \\
\text { analyze initial data } \\
\text { necessary for the } \\
\text { calculation of economic } \\
\text { and socio - economic } \\
\text { indicators characterizing } \\
\text { the activities of } \\
\text { economic entities (PC-1) } \\
\text { - ability to calculate } \\
\text { economic and socio- } \\
\text { economic indicators } \\
\text { characterizing the } \\
\text { activities of economic } \\
\text { entities on the basis of } \\
\text { standard methods and } \\
\text { the current regulatory } \\
\text { framework (PC-2) } \\
\text { Organizational and } \\
\text { managerial activities: } \\
\text { - the ability to organize } \\
\text { the activities of a small } \\
\text { group established to } \\
\text { implement a specific } \\
\text { economic project (PC-9) } \\
\text { - ability to use modern } \\
\text { technical means and } \\
\text { information technologies } \\
\text { to solve communicative } \\
\text { tasks (PC-10) }\end{array}$ \\
\hline $\begin{array}{l}\text { 2) } \\
\text { Preparation } \\
\text { of } \\
\text { consolidated } \\
\text { financial } \\
\text { statements }\end{array}$ & - PK-17 & $\begin{array}{l}\text { Organizational and } \\
\text { managerial activities: } \\
\text { - PC-9 } \\
\text { - PC-10 }\end{array}$ \\
\hline $\begin{array}{l}\text { 3) Internal } \\
\text { control of } \\
\text { accounting }\end{array}$ & $\begin{array}{l}-\mathrm{PC}-14 \\
-\mathrm{PC}-15 \\
-\mathrm{PC}-16\end{array}$ & $\begin{array}{l}\text { Settlement and } \\
\text { economic activities: } \\
\text { - PC-1 }\end{array}$ \\
\hline
\end{tabular}

\begin{tabular}{|c|c|c|}
\hline $\begin{array}{l}\text { Labour } \\
\text { function }\end{array}$ & $\begin{array}{l}\text { Professional competence } \\
\text { in accounting activities } \\
\text { (PC) }\end{array}$ & $\begin{array}{l}\text { Required competencies } \\
\text { from other kinds of } \\
\text { economic activities }\end{array}$ \\
\hline $\begin{array}{l}\text { and } \\
\text { preparation } \\
\text { of } \\
\text { accounting } \\
\text { (financial) } \\
\text { statements }\end{array}$ & - PC-17 & $\begin{array}{l}\text { - PC-2 } \\
\text { Organizational and } \\
\text { managerial activities: } \\
\text { - PC-9 } \\
\text { - PC-10 } \\
\text { - the ability to critically } \\
\text { evaluate the proposed } \\
\text { management solutions } \\
\text { and develop and justify } \\
\text { proposals for their } \\
\text { improvement, taking } \\
\text { into account the criteria } \\
\text { of socio - economic } \\
\text { efficiency, risks and } \\
\text { possible socio-economic } \\
\text { consequences (PC-11) }\end{array}$ \\
\hline $\begin{array}{l}\text { 4) tax } \\
\text { accounting } \\
\text { and } \\
\text { reporting, } \\
\text { tax planning }\end{array}$ & $\begin{array}{l}\text { - PC-17. } \\
\text { - ability to organize and } \\
\text { carry out tax accounting } \\
\text { and tax planning of the } \\
\text { organization (PC-18) }\end{array}$ & $\begin{array}{l}\text { Settlement and } \\
\text { economic activities: } \\
\text { - ability to perform } \\
\text { necessary for the } \\
\text { drafting of the economic } \\
\text { sections of plans } \\
\text { calculations to justify } \\
\text { them and present the } \\
\text { results of the work in } \\
\text { accordance with } \\
\text { established } \\
\text { organizational standards } \\
\text { (PC-3) } \\
\text { Organizational and } \\
\text { managerial activities: } \\
\text { - PC-9 } \\
\text { - PC-10 } \\
\text { - PC-11 }\end{array}$ \\
\hline $\begin{array}{l}\text { 5) financial } \\
\text { analysis, } \\
\text { budgeting } \\
\text { and cash } \\
\text { flow } \\
\text { management }\end{array}$ & - PC-18 & $\begin{array}{l}\text { Settlement and } \\
\text { economic activities: } \\
\text { - PC-1 } \\
\text { - PC-2 } \\
\text { - PC-3 } \\
\text { Organizational and } \\
\text { managerial activities: } \\
\text { - PC-9 } \\
\text { - PC-10 } \\
\text { - PC-11 }\end{array}$ \\
\hline
\end{tabular}
competence of educational activities is not sufficient for the performance of all labour functions. In addition, there is a lack of professional competence in the use and configuration of accounting automation programs. This does not meet the requirements of the digital economy.

The new draft of the professional standard "Accountant" is more consistent with reality. According to it, the accountant has five main work functions:

- Maintain accounting records (level 5). (level 6).

- Prepare and submit accounting (financial) statements

- Report for the company with divisions (level 7).

- Prepare and submit consolidated financial statements (level 8) 
- Provide services in the field of accounting (level 8).

In our opinion, the formulation of the purpose of professional activity of the accountant, which is the most corresponding to modern tendencies, is the formation of accounting and analytical information necessary for interested internal and external users for making administrative decisions.

Further long-term development of the Accounting profession involves not only the availability of substantive knowledge and experience, as well as a creative approach, developed emotional intelligence, a conceptual vision of the problems and prospects of the company and confident knowledge of IT-technologies. The most important priority here is to perform functional duties, adhering to ethical standards. This is evidenced by the ACCA in its report "The future of accountancy". Faye Chua, ACCA, considers that "Professional accountants must maintain their technical excellence and strong ethical grounding, and supply this with certain personal skills and qualities".

\section{CONCLUSION}

As a member of the company's management system, an accountant needs not only professional knowledge, but also soft skills - qualities that include communication and leadership skills. It is established that people, whose activity is connected with figures and calculations, have more developed logical thinking than figurative. This is primarily due to the nature of the people who choose the profession of Accountant. They are usually initially more inclined to analyze and work with figures and facts than with people. Secondly, the specificity of training on economic professions in higher educational institutions of Russia involves more attention to the technical and core subjects than the development of practical communication skills. In practice, the accountant constantly interacts with employees and management. A high level of emotional intelligence helps to build communication with people in the business sphere, and also to ask the right questions and make the right decisions.

Currently, many professional accounting communities have already realized the need to develop emotional intelligence and its role in business communication. For example, the Institute of chartered accountants of Australia has developed a special program for accountants to improve emotional intelligence. The New York Community of professional accountants regularly covers this important topic in its professional publications. Moreover, in 2016, ASSA identified emotional intelligence as one of the necessary professional skills, without which in the future one cannot do.

ACCA has gone further and suggested such professional success factor as Vision (VQ). VQ is the ability to anticipate future trends accurately by extrapolating existing trends and facts, and filling the gaps by thinking innovatively. This is certainly a new look at such an ancient profession - an Accountant.

Today a professional accountant should not only possess knowledge, gain experience and behave in accordance with ethical norms, but also be ready to use the available knowledge in a new situation, establish connections, study the possible results and consequences of economic transactions and generate new ideas.

\section{References}

[1] R. R. Azmitov, I. A. Ivanovskiy, L. L. Korabelnikova, 2014. Features of Russian Companies Real Estate Appraisal in the Accounting System, Mediterranean Journal of Social Sciences, no. 5 (24), pp. 242-245.

[2] R.R. Azmitov, and L.L. Korabelnikova, Problems of implementation of management accounting automation in Russia. Mediterranean Journal of Social Sciences, 2015, Vol. 6, №1S3, pp. 384-385.

[3] O.S. Bezvidnaya, and N.V. Lopukhova, Methodological issues of economic analysis at various stages of reorganization of legal entities. Mediterranean Journal of Social Sciences, 2015, Vol. 6, №1S3, pp. 370374.

[4] T. V. Elsukova, Lean accounting and throughput accounting: An integrated approach. Mediterranean Journal of Social Sciences, 2015, Vol.6 (3), pp. 83-87

[5] K. M. Garifullin, V. B. Ivashkevich, A. Yu. Sokolov, E. A. Astrakhantseva, A. R. Gubaydullina, The formation and use of information accounting for managerial decision making, Moscow, Publishing house LLC «Rusyns», 2016.

[6] L. Garifova, The Economy of the Digital Epoch in Russia: Development Tendencies and Place in Bisiness, Procedia Economics and Finance, no. 15, 2014, pp. $1159-1164$.

[7] A. Golyshko, Problems of formation of the digital economy and possible solutions. https://www.eg-online.ru/article/365284/

[8] V.B. Ivashkevich, N.S. Spiryagina, The resposibility for the faithfulness of the accounting statements of enterprises. Mediterranean Journal of Social Sciences, 2015, Vol. 6, №1S3, pp. 357-360.

[9] R. G. Kaspina, L. A. Molotov and L. E. Kaspin, The IFRS impact on effectiveness of a company's economic security system, Social Sciences and Interdisciplinary Behavior - Proceedings of the 4th International Congress on Interdisciplinary Behavior and Social Science, ICIBSOS 2015, 2016, pp. 65-70.

[10] R. G. Kaspina, L. A. Molotov, Corporate integrated reporting: An efficient tool of economic security management, Academy of Strategic Management Journal, no. 15, 2016, pp. 225-232.

[11] S. A. Kuzubov, Foresight financial occupations: accountants and auditors (results of the round table), Journal of Corporate Finance Research, Vol.10, №4, 2016.

[12] N. Lopuhova, O. Bezvidnaya, The way a student selects a specialisation in economic higher education institution, Procedia - Social and Behavioral Sciences, 2014, no. 152, pp. 1087-1090.

[13] S.E. Markaryan, T. A. Snetkova, D. V. Khairullina, Administrative aspects of accounting organization. Russian experience and problems. Life Science Journal, 2014, 11(8), pp. 107-111.

[14] B.E. Needles, M. Powers, M.L. Frigo, A.I. Shigaev, Integrated reporting and sustainability reporting: An exploratory study of high performance companies, Performance Measurement and Management Control: Contemporary Issues. Studies in Managerial and Financial Accounting, Volume 31, 2016, pp. 41-81.

[15] L.A. Plotnikova, V.V. Plotnikova, Disclosure of information about internal control system in corporate reporting, International Business Management, Volume 10, Issue 24, 2016, pp. 5746-5751.

[16] Professional accountants - the future: Drivers of change and future skills. http://www.accaglobal.com/content/dam/membersbeta/images/campaigns/pa-tf/pi-professional-accountants-the-future.pdf

[17] I. Stukalova, A.Shishkin, A. Stukalova, Internationalization of higher education: A case of Russian universities Economics and Sociology, no. $8(1), 2016$, pp. $275-286$ 
